\title{
PENGARUH BAHAN KEMASAN DAN LAMA INKUBASI TERHADAP KUALITAS TEMPE KACANG GUDE SEBAGAI SUMBER BELAJAR IPA
}

\author{
Sayuti \\ SMPN 1 Pesawaran Lampung \\ E-mail: sayuti7105@ymail.com
}

\begin{abstract}
Pigeon pea can be used as an alternative of soybeans that contain protein, fats, and carbohydrates. Objective: (1) determine the effect of various packaging on the quality of pigeon pea tempe, (2) the effect of long incubation on the quality of pigeon pea tempe, (3) the interaction of various packaging and long incubation on the quality of pigeon pea tempeh. (4) design the research results as a science learning resource for $9^{\text {th }}$ grade junior high school on the topic of biotechnology. The research design used completely randomized design. Research conducted at the Laboratory of Food Products Technology in Polinela in May $11^{\text {th }}$ until $25^{\text {th }}$, 2015. Data were analyzed using SPSS 16.0, the data proximate using Univariate and Tukey, the data organoleptic using Friedman test. From the results of the proximate analysis turns out there is influence between the packaging materials and the long incubation of the tempe quality. Protein content increased, while fat and carbohydrates decreases with increasing time of incubation. Organoleptic analysis of the soybean leaves are packed with incubation time 36 and 42 hours is preferred by the panelists than plastic packaging with an incubation time of 48 hours. The results of the research can be used to design learning resources of scince for junior high School, based LKPD Form based scientific approach.
\end{abstract}

Kata Kunci: Bahan kemasan, lama inkubasi, kacang gude, kualitas tempe, sumber belajar

Gizi yang terkandung dalam makanan mempunyai fungsi yang berbeda-beda. Karbohidrat berfungsi sebagai sumber energi, lemak sebagai cadangan makanan dan energi, serta protein untuk membantu proses pertumbuhan dalam pembentukan otot dan sel-sel di dalam tubuh.

Protein yang diperlukan oleh tubuh ada dua macam. Protein hewani dihasilkan oleh hewan seperti pada daging, susu dan telur, sedangkan protein nabati terdapat pada padipadian dan kacang-kacangan. Salah satu olahan sebagai sumber protein adalah tempe.

Tahapan pembuatan tempe antara lain; perendaman, perebusan, peragian, pengemasan, dan fermentasi (inkubasi). Selama inkubasi akan terjadi perubahan-perubahan zat yang terkandung dalam biji kacang akibat dari kerja jamur (kapang) Rhizopus sp. yang merubah senyawa-senyawa kompleks menjadi senyawa-senyawa sederhana, sehingga jika dikonsumsi manusia akan lebih mudah dicerna. Menurut Hidayat dkk, (2006: 93) starter tempe adalah bahan yang mengandung biakan jamur tempe, digunakan sebagai agen yang mengubah kedelai rebus menjadi tempe akibat tumbuhnya jamur tempe pada kedelai dan melakukan kegiatan fermentasi yang menyebabkan kedelai 
berubah karakteristiknya menjadi tempe.

Kedelai merupakan bahan yang digunakan untuk membuat tempe. Kelangkaan kedelai sering terjadi di Indonesia, kelangkaan kedelai tentunya dapat diatasi dengan menggunakan bahan lain sebagai alternatif pembuatan tempe. Salah satu upaya yang dilakukan adalah dengan mengoptimalkan potensi kacangkacang lokal sebagai pengganti kedelai.

Kacang gude (Cajanus cajan (L.) Mills) termasuk jenis tumbuhan kacang-kacangan yang banyak ditanam oleh masyarakat sebagai tanaman pekarangan. Gude tanaman tahunan, tahan terhadap cuaca panas dan di tanah kering. Biji muda dimanfaatkan sebagai bahan sayur-mayur, biji tua sebagai bahan pangan alternatif. Gude memiliki gizi yang cukup baik sama dengan kacang-kacangan lain. Setiap 100 gram mengandung energi sebesar 336 kilokalori, protein 20,7 gram, karbohidrat 62 gram, lemak 1,4 gram, kadar air 12,2 gram.

Kemasan alami yang umum digunakan untuk membungkus tempe adalah daun-daunan dari tanaman seperti daun pisang, daun waru, daun jati, dll. Sekarang ini kemasan dari plastik lebih dipilih oleh masyarakat. Menurut Kamus Bahasa Indonesia (2006: 76) kemasan adalah suatu barang yang dipakai untuk membalut sesuatu agar tidak kelihatan atau lepas. Menurut Basriman (2010: 1) Pengemasan adalah wadah atau pembungkus yang dapat membantu mencegah atau mengurangi terjadinya kerusakan-kerusakan pada bahan yang dikemas/dibungkusnya.

Menurut Suprapti (2003: 51) bahwa pembungkusan tempe menggunakan daun sama halnya dengan menyimpannya dalam ruang gelap (salah satu syarat ruang fermentasi), mengingat daun yang tidak tembus pandang. Disamping itu aerasi (sirkulasi udara) dapat tetap berlangsung melalui celah-celah pembungkus yang ada. Kapang tempe membutuhkan banyak oksigen untuk pertumbuhannya (Sarwono dalam Astuti, 2009: 16)

Menurut Hidayat dkk (2006: 95) faktor utama yang menentukan bahwa pembungkus dapat menghasilkan tempe yang baik ialah aerasi dan kelembaban. Jika tempat pengemasan dapat menjamin aerasi yang merata secara terus menerus dan sekaligus dapat menjaga agar kelembaban tetap tinggi tanpa menimbulkan pengembunan. Kelembaban yang cocok untuk pertumbuhan kapang adalah $90-95 \%$.

Kemasan plastik merupakan kemasan modern, dan kemasan ini lebih sering dipilih dan digunakan oleh produsen makanan sebagai wadah karena lebih praktis dan tidak merepotkan. Kelemahan dari kemasan ini adalah bekas dari kemasan plastik akan menjadi limbah anorganik yang sulit dibusukkan. Menurut Suprapti (2003: 51) kantong plastik juga dapat digunakan untuk membungkus tempe. Namun karena bersifat kedap udara maka permukaan plastik harus dilubangi agar supaya aerasi dapat terjadi.

Produk yang dibungkus oleh daun biasanya memilik aroma yang khas karena daun mengandung polifenol. Mastuti \& Handayani (2014: 60) mengutip penelitian Sahaa dkk., bahwa ekstrak daun pisang mengandung asam galat yang merupakan tipe dari katekin. Katekin termasuk dalam golongan polifenol dan merupakan salah satu senyawa sumber penghasil aroma.

Inkubasi dimaksudkan untuk menumbuhkan kapang. Menurut Dania (dalam Susiati, 2014: 15) proses 
$\begin{array}{lrr}\text { fermentasi } & \text { merupakan } & \text { proses } \\ \text { bioteknologi } & \text { sederhana } & \text { yang }\end{array}$ memanfaatkan enzim atau mikroba/ mikroorganisme sebagai sumber enzim, namun sampai saat ini industri fermentasi masih memanfaatkan mikroba sebagai sumber enzim, karena cara ini lebih mudah dan murah. Hidayat, dkk (2006:99) berpendapat bahwa Inkubasi dilakukan pada suhu $25^{\mathrm{O}}-37^{\mathrm{O}}$ selama $36-48$ jam. Selama inkubasi terjadi proses fermentasi yang menyebabkan perubahan-perubahan komponen dalam biji kedelai. Persyaratan tempat yang dipergunakan untuk inkubasi adalah kelembaban, kebutuhan oksigen dan suhu yang sesuai dengan pertumbuhan jamur.

Kandungan gizi (protein, lemak dan karbohidrat) akan berubah seiring dengan bertambahnya waktu inkubasi. Protein kasar pada tempe lebih rendah dibandingkan dengan kandungan protein pada bahan bakunya hal ini terjadi akibat proses perebusan. Panasnya air akibat perebusan akan menyebabkan hilangnya (rusak) protein. Pemanasan sebaiknya tidak terlalu lama yang dapat menyebabkan banyak protein yang hilang (Salim, 2012: 36). Namun kadar protein akan mengalami kenaikan dengan meningkatnya waktu fermentasi (Dewi, 2010: 27).

Kadar lemak juga mengalami perubahan akibat dari aktivitas kapang. Semakin lama waktu fermentasi kadar lemak tempe semakin menurun (Dewi, 2010: 29). Kadar lemak kedelai akan mengalami penurunan akibat fermentasi menjadi tempe. Lebih dari 1/3 lemak netral (monogliserida, digliserida, trigliserida) dari kedelai terhidrolisis olehenzim lipase selama 3 hari fermentasi oleh $R$. oligosporus yang bersifat lipotik pada $\mathrm{T} 37^{\mathrm{O}} \mathrm{C}$ (Kasmidjo dalam Dewi, 2010:29).
Kadar karbohidrat pada tempe selama proses fermentasi mengalami penurunan karena dirombak menjadi gula-gula sederhana akibat dari aktifitas enzim amylase, selulase, xylanase, dan lain-lain (Hidayat, 2006:102).

Dahulu pembelajaran berpusat pada pendidik (teacher centered), saat ini berubah pada pembelajaran yang berpusat pada peserta didik (student centered). Lembar Kegiatan Peserta Didik (LKPD) adalah salah satu jenis sumber belajar yang sangat tepat digunakan dalam pembelajaran siswa aktif. Dari pengamatan langsung di sekolah masih banyak pendidik memakai LKPD yang dibuat oleh penerbit. LKPD tersebut belum tentu sesuai dengan keadaan lingkungan, materi dan karakteristik peserta didik. Agar supaya sesuai dengan hal tersebut di atas tentunya LKPD harus dirancang sendiri oleh pendidik. Hal ini akan memberikan dampak yang baik kepada pendidik dimana pendidik akan lebih kreatif dan inovatif, sementara bagi peserta didik alam memberikan pengalaman baru yang sesuai dengan kemampuan dan keadaan lingkungannya.

Berdasarkan latar belakang masalah di atas maka rumusan masalah pada penelitian ini adalah: 1) Apakah terdapat pengaruh berbagai bahan kemasan terhadap kualitas tempe kacang gude, 2) Apakah terdapat pengaruh lama inkubasi terhadap kualitas tempe kacang gude, 3) Apakah terdapat interaksi berbagai bahan kemasan dan lama inkubasi terhadap kualitas tempe kacang gude, 4) Bagaimana-kah merancang hasil penelitian sebagai sumber belajar IPA.

Tujuan yang akan dicapai dalam penelitian ini adalah untuk: 1) mengetahui pengaruh berbagai bahan kemasan terhadap kualitas tempe 
kacang gude, 2) mengetahui pengaruh lama inkubasi terhadap kualitas tempe kacang gude, 3) mengetahui interaksi berbagai bahan kemasan dan lama inkubasi terhadap kualitas tempe kacang gude, 4) merancang hasil penelitian sebagai sumber belajar IPA SMP kelas IX pada topik Bioteknologi Pangan.

\section{METODE}

Pada penelitian ini digunakan pendekatan penelitian kuantitatif dengan model penelitian eksperimen dimana tempe yang berasal dari biji kacang gude digunakan sebagai obyek penelitian. Rancangan dalam penelitian ini menggunakan rancangan acak lengkap (RAL). Kelompok pertama adalah kelompok perlakuan yang menggunakan berbagai bahan kemasan tempe yang umum digunakan oleh masyarakat yaitu daun pisang, daun waru dan kemasan plastik, dan kelompok kedua adalah lama inkubasi tempe yakni 36 jam, 42 jam dan 48 jam.

Tabel 1. Teknik Pengumpulan Data Analisis Proksimat (Sumber: Susiati, 2014: 43)

\begin{tabular}{|c|c|c|c|c|}
\hline \multirow{2}{*}{\multicolumn{2}{|c|}{ Perlakuan }} & \multicolumn{3}{|c|}{ Berbagai Kemasan Tempe } \\
\hline & & Daun Pisang $\left(A_{1}\right)$ & Daun Waru $\left(\mathbf{A}_{2}\right)$ & Plastik $\left(\mathbf{A}_{3}\right)$ \\
\hline \multirow{3}{*}{ 鸹 } & $36 \operatorname{Jam}\left(\mathbf{B}_{1}\right)$ & $\mathrm{A}_{1} \mathrm{~B}_{1}$ & $\mathrm{~A}_{2} \mathrm{~B}_{1}$ & $A_{3} B_{1}$ \\
\hline & $42 \mathrm{Jam}\left(\mathrm{B}_{2}\right)$ & $\mathrm{A}_{1} \mathrm{~B}_{2}$ & $\mathrm{~A}_{2} \mathrm{~B}_{2}$ & $\mathrm{~A}_{3} \mathrm{~B}_{2}$ \\
\hline & $48 \mathrm{Jam}\left(\mathrm{B}_{3}\right)$ & $\mathrm{A}_{1} \mathrm{~B}_{3}$ & $\mathrm{~A}_{2} \mathrm{~B}_{3}$ & $\mathrm{~A}_{3} \mathrm{~B}_{3}$ \\
\hline
\end{tabular}

Keterangan:

A1B1 : Tempe dikemasan daun pisang diinkubasi selama 36 jam

A1B2 : Tempe dikemasan daun pisang diinkubasi selama 42 jam

A1B3 : Tempe dikemasan daun pisang diinkubasi selama 48 jam

A2B1 : Tempe dikemasan daun waru diinkubasi selama 36 jam

A2B2 : Tempe dikemasan daun waru diinkubasi selama 42 jam

A2B3 : Tempe dikemasan daun waru diinkubasi selama 48 jam

A3B1 : Tempe dikemasan plastik diinkubasi selama 36 jam

A3B2 : Tempe dikemasan Pastik diinkubasi selama 42 jam

A3B3 : Tempe dikemasan plastik diinkubasi selama 48 jam

Tabel 2. Penentuan Kandungan Gizi Tempe Kacang gude (Analisis Proksimat)

\begin{tabular}{cll}
\hline No & \multicolumn{1}{c}{ Analisis } & \multicolumn{1}{c}{ Metode } \\
\hline 1 & Protein & Metoda Gunning \\
\hline 2 & Lemak & Metoda soxhlet \\
\hline 3 & Karbohidrat & Metoda Oven/AOAC1970, Ranggana 1979 \\
\hline
\end{tabular}

\section{Penentuan Respon Panelis (Uji} Organoleptik)

Uji organoleptik dikenal dengan uji kesukaan dilakukan dengan menggunakan indra (organ sensorik) yang meliputi warna, aroma, rasa dan tekstur dari masing-masing perlakuan.
Data Analisis proksimat diolah dengan menggunakan metode Rancangan Acak Lengkap (RAL) dengan teknik analisis Two Way Anova (Anava 3 x 3).. Uji organoleptik diolah dengan menggunakan metode Friedman Test. 


\section{HASIL}

\section{Analisis Proksimat}

Tabel3. Data Rata-rata Hasil Analisis Proksimat Pada Tempe kacang Gude

\begin{tabular}{|c|c|c|c|c|}
\hline & \multirow{2}{*}{$\begin{array}{c}\text { Tempe } \\
\text { Kacang Gude }\end{array}$} & \multicolumn{3}{|c|}{ Kandungan (\%) } \\
\hline & & Protein & Lemak & Karbohidrat \\
\hline \multirow{9}{*}{ 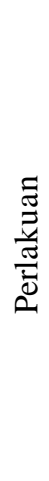 } & A1B1 & 8.5702 & 0.2462 & 28.2237 \\
\hline & $\mathrm{A} 1 \mathrm{~B} 2$ & 10.1133 & 0.2222 & 24.6923 \\
\hline & A1B3 & 11.7176 & 0.1811 & 21.1092 \\
\hline & $\mathrm{A} 2 \mathrm{~B} 1$ & 11.4987 & 0.3547 & 23.6795 \\
\hline & $\mathrm{A} 2 \mathrm{~B} 2$ & 12.6385 & 0.3063 & 22.8262 \\
\hline & A2B3 & 13.3942 & 0.2423 & 19.1586 \\
\hline & $\mathrm{A} 3 \mathrm{~B} 1$ & 10.0921 & 0.3510 & 20.0102 \\
\hline & A3B2 & 10.7929 & 0.2364 & 17.2273 \\
\hline & A3B3 & 11.6307 & 0.1715 & 16.0424 \\
\hline
\end{tabular}

\section{Uji Organoleptik}

Tabel 4. Data Rata-rata Hasil Analisis Organoleptik Pada Tempe kacang Gude

\begin{tabular}{|c|c|c|c|c|c|}
\hline \multirow{2}{*}{\multicolumn{2}{|c|}{ Tempe Kacang Gude }} & \multicolumn{4}{|c|}{ Indikator } \\
\hline & & Warna & Aroma & Rasa & Tekstur \\
\hline \multirow{9}{*}{ 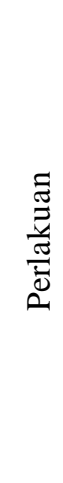 } & A1B1 & 2.00 & 2.35 & 2.00 & 2.60 \\
\hline & A1B2 & 3.21 & 2.55 & 2.35 & 2.25 \\
\hline & A1B3 & 2.60 & 2.10 & 1.85 & 2.35 \\
\hline & A2B 1 & 2.15 & 1.85 & 2.10 & 1.85 \\
\hline & $\mathrm{A} 2 \mathrm{~B} 2$ & 3.05 & 2.35 & 1.95 & 2.80 \\
\hline & A2B3 & 2.35 & 2.25 & 1.70 & 2.05 \\
\hline & A3B 1 & 1.95 & 1.65 & 1.85 & 2.00 \\
\hline & A3B2 & 2.55 & 1.90 & 1.30 & 2.45 \\
\hline & A3B3 & 1.10 & 1.70 & 1.30 & 2.35 \\
\hline
\end{tabular}

\section{PEMBAHASAN}

Bahan kemasan dan lama inkubasi memberikan pengaruh yang berarti (signifikan) terhadap kualitas tempe kacang gude. Kedua perlakuan secara bersama-sama juga memberikan interaksi yang signifikan terhadap kualitas tempe kacang gude.
Bahan kemasan yang berbeda ternyata memberikan pengaruh yang berbeda pula pada kandungan protein, tempe kacang gude yang dibungkus dengan daun waru memiliki nilai kandungan protein yang lebih tinggi dibandingkan dengan tempe yang dikemas dengan daun pisang dan plastik. Lemak yang terkandung di dalam tempe kacang 
gude juga memiliki nilai yang berbeda pada masing-masing kemasan yang digunakan. Kemasan daun waru dapat memberikan pengaruh yang lebih tinggi terhadap kandungan lemak dibandingkan dengan kemasan dari daun pisang dan plastik. Pada tempe kacang gude yang dikemas dengan daun pisang ternyata memiliki nilai yang lebih tinggi dibandingkan dengan kemasan daun waru dan plastik. Dengan demikian kemasan dari bahan daun memiliki pengaruh yang lebih tinggi dibandingkan dengan bahan kemasan dari plastik terhadap kualitas tempe kacang gude.

Penyebab hal tersebut adalah bahan kemasan yang berasal dari daun kedap cahaya (tidak tembus cahaya), sirkulasi udara (aerasi) dapat terjadi dengan baik melalui celah-celah pada daun sehingga oksigen lebih mudah masuk ke dalam kemasan. Dengan sirkulasi udara yang baik menyebabkan kelembaban dapat terjaga dengan baik. Ketiga faktor tersebut akan mendukung pertumbuhan kapang selama proses fermentasi sedangkan kemasan plastik tidak kedap cahaya, sirkulasi udara tergantung pada jumlah lubang yang diberikan, begitu juga kelembaban tergantung pada sirkulasi udara akibat dari pemberian lubang pada kemasan.

Pendapat Suprapti (2003: 51) bahwa pembungkusan tempe menggunakan daun sama halnya dengan menyimpannya dalam ruang gelap (salah satu syarat ruang fermentasi), mengingat daun yang tidak tembus pandang. Disamping itu aerasi dapat tetap berlangsung melalui celah-celah pembungkus yang ada. Sarwono, 2005 dalam Astuti, 2009: 16 juga berpendapat bahwa kapang tempe membutuhkan membutuhkan banyak oksigen untuk pertumbuhannya. Menurut Hidayat (2006: 95) faktor utama yang menentukan bahwa pembungkus dapat menghasilkan tempe yang baik ialah aerasi dan kelembaban. Jika tempat pengemasan dapat menjamin aerasi yang merata secara terus menerus dan sekaligus dapat menjaga agar kelembaban tetap tinggi tanpa menimbulkan pengembunan. Kelembaban yang cocok untuk pertumbuhan kapang adalah $90-95 \%$.

Lama inkubasi yang berbeda juga memberikan pengaruh pada perbedaan kualitas tempe. Kandungan protein pada inkubasi 42 jam memiliki pengaruh yang lebih tinggi dibandingkan dengan inkubasi 36 jam, inkubasi 48 jam lebih tinggi dibandingkan dengan inkubasi 42 jam. Dengan demikian semakin lama inkubasi dilakukan maka akan semakin meningkatkan kandungan protein pada tempe kacang gude. hal ini terjadi karena selama proses inkubasi akan terjadi perubahanperubahan komponen kimiawi pada biji kacang gude.

Selama proses inkubasi akan terjadi aktivitas proteolitik dari kapang yang mengurai protein menjadi asam amino sehingga menyebabkan peningkatan nitrogen. Selain itu juga selama fermentasi akan mengalami berkurangnya kandungan oligosakarida penyebab flatulensi (keluarnya gas). Akibat hal tersebut akan terjadi peningkatan asam amino bebas.

Pendapat Suprihatin (2010: 4142) bahwa selama proses fermentasi, akan mengalami perubahan baik fisik maupun kimianya. Dengan adanya aktivitas proteolitik dari kapang akan mengurai protein menjadi asam amino, sehingga nitrogen terlarutnya 
akan mengalami peningkatan. Murata, dkk dalam Suprihatin, 2010:42 juga berpendapat bahwa perubahan lain yang terjadi selama fermentasi adalah berkurangnya kandungan oligosakarida penyebab flatulence. Seiring dengan penurunan tersebut terjadi peningkatan asam amino bebas yang mencapai jumlah terbesar pada 72 jam fermentasi. Menurut Dewi, 2010: 27 bahwa kadar protein akan mengalami kenaikan dengan meningkatnya waktu fermentasi.

Dengan adanya pengaruh bahan kemasan dan juga lama inkubasi terhadap kandungan protein di atas maka dapat dijelaskan pula bahwa kedua perlakuan tersebut juga memberikan interaksi terhadap kandungan protein pada kacang gude. Interaksi yang tertinggi terdapat pada tempe kacang gude yang dikemas dengan menggunakan daun waru dan diinkubasi selama 48 jam.

Perbedaan waktu inkubasi memberi pengaruh perbedaan pada kandungan lemak tempe. Waktu inkubasi 36 jam memiliki kandungan lemak lebih tinggi dari pada tempe yang diinkubasi selama 42 jam, begitu juga dengan inkubasi 42 jam lebih tinggi dibandingkan dengan inkubasi 48 jam. Dengan kata lain semakin lama waktu inkubasi maka akan menyebabkan kandungan lemak semakin menurun. Hal ini diakibatkan adanya proses fermentasi dimana kapang akan menguraikan lemak yang terdapat pada biji kacang.

Pembebasan lemak ditandai dengan meningkatnya asam lemak selama fermentasi. Penurunan ini juga di akibatkan peran dari enzim lipase yang meningkatkan asam lemak bebas yang dimulai pada masa
12 jam fermentasi. Hal serupa dikemukakan oleh Kasmidjo dalam Dewi (2010: 29) bahwa kadar lemak kacang (kedelai) akan mengalami penurunan akibat dari fermentasi menjadi tempe. Lebih dari 1/3 lemak netral (monogliserida, digliserida, trigliserida) dari kacang (kedelai) terhidrolisis oleh enzim lipase selama 3 (tiga) hari fermentasi oleh Rhizopus oligosporus yang bersifat lipotik pada temperature $37^{\circ} \mathrm{C}$.

Dari uraian tentang pengaruh bahan kemasan dan lama inkubasi terhadap kandungan lemak maka dapat dikatakan pula bahwa kedua perlakuan tersebut juga memberikan interaksi terhadap kandungan lemak. Tempe kacang gude yang dikemas dengan menggunakan daun waru yang diinkubasi selama 36 jam memiliki nilai kandungan lemak yang lebih tinggi dibandingkan dengan perlakuan lain.

Semakin lama waktu inkubasi pada proses pembuatan tempe kacang gude maka kandungan karbohidrat akan semakin menurun. Interaksi antara bahan kemasan dan lama inkubasi terhadap kandungan karbohidrat terdapat nilai tertinggi pada tempe yang dikemas dengan menggunakan daun pisang yang diinkubasi selama 36 jam, 42 jam, dan 48. Kemudian diikuti kemasan daun waru yang diinkubasi selama 36 jam, 42 jam, dan 48, dan yang terendah pada tempe yang dikemas dengan plastik.

Penurunan ini disebabkan oleh karena selama inkubasi kapang Rhizopus olegosporus menghasilkan enzim seperti amylase, selulase, xylanase yang mendegradasi karbohidrat dalam tempe kacang gude. Hidayat (2006:102) berpendapat bahwa kadar karbohidrat pada tempe selama 
proses fermentasi mengalami penurunan karena dirombak menjadi gula-gula sederhana akibat dari aktivitas enzim amylase, selulase, xylanase, dan lain- lain.

Dari hasil analisis statistik pada Interaksi antara bahan kemasan dan lama inkubasi terhadap kandungan protein, lemak dan karbohidrat pada tempe kacang gude dapat dijelaskan bahwa bahan kemasan dan lama inkubasi yang berbeda akan memberikan interaksi yang berbeda pula pada kualitas tempe kacang gude (kandungan protein, lemak, dan karbohidrat). Pada kandungan protein, kemasan daun waru dengan inkubasi 48 jam memberikan interaksi tertinggi. Terhadap kandungan lemak, interaksi tertinggi pada tempe yang dikemas dengan daun waru dan diinkubasi selama 36 jam, dan terhadap kandungan karbohidrat interaksi tertinggi terdapat pada tempe kacang gude yang dikemas dengan daun dan diinkubasi selama 36 jam.

Hasil analisis uji organoleptik yang mencakup warna, aroma, rasa, dan tekstur menggunakan analisis statistik SPSS versi 16.0 model Friedman Test bahwa respon 20 panelis terhadap warna tempe kacang gude berbeda nyata dari 9 (sembilan) perlakuan. Secara berurutan respon panelis terhadap Sembilan perlakuan adalah A1B2, A2B2, A3B2, A1B3, A2B3, A2B1, A1B1, A3B1, dan A3B3.

Warna khas dari tempe adalah putih, warna ini dikarenakan adanya warna miselia kapang yang tumbuh pada permukaan kacang. Panelis lebih cenderung memilih tempe yang dikemas dari daun pisang dan daun waru dengan masa inkubasi 42 jam dibandingkan dengan kemasan platik, karena dimungkinkan warna pada kemasan daun lebih putih dikarenakan kemasan daun kedap cahaya dan belum lama difermentasi sehingga kondisi kapang masih aktif dalam masa pertumbuhan. Respon yang berbeda pada panelis dikarenakan penerimaan seseorang terhadap warna berbeda dipengaruhi oleh berbagai faktor seperti faktor alam, geografis, aspek social dan lain-lain. Menurut Winarno (1997) dalam Asturi (2009: 38) bahwa penerimaan warna suatu bahan makanan tergantung pada faktor alam, geografis, dan aspek sosial masyarakat penerima. Respon panelis terhadap warna tempe kacang gude dapat dilihat pada tabel berikut ini:

Aroma juga memegang peranan dalam suatu prodak pangan, aroma yang banyak dipilih menandakan produk tersebut lebih disukai oleh konsumen. Winarno dalam Astuti (2009: 38) berpendapat bahwa bau makanan banyak menentukan kelezatan bahan makanan. Panelis memberikan respon yang berbeda nyata terhadap aroma tempe pada 9 (sembilan) perlakuan yang dilakukan. Ranking respon secara berurut adalah A1B2, A1B1, A2B2, A2B3, A1B3, A2B1, A3B2, A3B1, dan A3B3. Kecenderungan panelis memberikan respon positif pada kemasan dari daun pisang dan daun waru yang difermentasi 36 jam dan 42 jam dibandingkan dengan yang dikemas dengan menggunakan plastik, hal ini tentunya dikarenakan kemasan daun memberikan aroma harum yang mudah diterima oleh indera pembau masyarakat, dan waktu fermentasi 36 jam dan 42 jam tempe masih segar karena kapang masih dalam masa pertumbuhan. Hal tersebut serupa dengan hasil penelitian Sahaa dkk. yang dikutip 
oleh Mastuti \& Handayani (2014:60) bahwa daun pisang mengandung asam galat yang merupakan tipe dari katekin. Katekin termasuk dalam golongan polifenol dan merupakan salah satu senyawa sumber penghasil aroma.

Rasa merupakan komponen yang sangat penting untuk menentukan penerimaan konsumen terhadap makanan. Kemasan daun dengan inkubasi 36 jam dan 42 jam lebih banyak direspon oleh panelis, dan respon terendah adalah tempe yang dikemas oleh plastik yang diinkubasi 48 jam. Hal ini menurut peneliti diakibatkan karena tempe yang dikemas dengan plastik dan waktu inkubasi 42 dan 48 jam sudah mulai menuju pada proses pembusukan atau pertumbuhan jamur mulai mengalami penurunan sehingga menyebabkan rasa lebih pahit.

Tektur tempe lebih lembut jika dibandingkan dengan biji kacang yang sudah direbus. Lembutnya tempe tentunya karena peran dari kapang yang melakukan fermentasi sehingga menyebabkan perubahan fisik kacang gude menjadi lebih lembut, dengan alasan tersebut sehingga tempe lebih mudah dicerna dibandingkan dengan kacang sebagai bahan bakunya. Responden lebih menganggap tektur lebih lunak terdapat pada perlakuan A2B2 kemudian secara berurut A1B1, A3B2, A3B3, A1B3, A1B2, A2B3, A3B1, DAN A2B1. Rata-rata tingkatan tektur dapat dikatakan kurang lunak. Hal ini dikarenakan miselia-miselia pada kapang yang menghubungkan antara biji kacang. Tekstur dapat diketahui dari lebat atau tidaknya miselia yang tumbuh pada permukaan tempe. Apabila miselia tampak lebat maka tempe membentuk masa yang lebih kompak dan tekstur lebih padat.

Dari penelitian yang telah dilakukan diperoleh konsep, fakta, prinsip dan prosedur yang kemudaian dilakukan analisis potensi berdasarkan pada kurikulum, karakteristik materi, karakteristik peserta didik, kondisi lingkungan dan tujuan pembelajaran. Hasil penelitian ini dapat digunakan sebagai bahan untuk merancang sumber belajar peserta didik pada konsep bioteknologi kelas IX SMP.dari proses sampai kepada hasil penelitian yang merujuk pada 3 domain pembelajaran yaitu Kognitif, Afektif dan Psikomotorik untuk dapat dijadikan sebagai acuan dalam proses maupun penilaian dalam menyampaikan materi tentang bioteknologi. Penerapan dalam kegiatan pembelajaran dari hasil penelitian ini dapat dikemas dalam bentuk Lembar Kegiatan Peserta Didik (LKPD) dengan menggunakan pendekatan saintifik model Project Based Learning (PJBL). LKPD yang disusun dapat dijadikan sebagai petujuk praktikum peserta didik.

\section{KESIMPULAN DAN SARAN Kesimpulan}

Bahan kemasan memberikan pengaruh terhadap kualitas tempe kacang gude dinilai dari kandungan protein, lemak dan karbohidrat. Kemasan yang berasal dari daun waru memberi pengaruh tertinggi pada kandungan protein dan lemak sedangkan pada kandungan karbohidrat kemasan daun pisang memiliki pengaruh yang lebih tinggi. Dengan demikian kemasan yang berasal dari daun memiliki pengaruh terhadap kualitas tempe yang lebih tinggi dibandingkan dengan tempe yang dikemas dengan plastik hal 
tersebut dikarenakan pada kemasan yang berasal dari daun kedap cahaya, aerasi terjadi dengan baik karena udara dapat bersirkulasi sehingga oksigen lebih mudah bertukar, dan kelembaban lebih terjaga dibandingkan dengan dengan kemasan yang berasal dari plastik.

Lama inkubasi memberikan pengaruh terhadap kualitas tempe kacang gude dinilai dari kandungan protein, lemak dan karbohidrat. Kandungan protein akan meningkat seiring bertambahnya waktu inkubas, nilai tertinggi terdapat pada tempe yang diinkubasi selama 48 jam. Hal ini disebabkan karena adanya aktivitas proteolitik dari kapang yang akan mengurai protein menjadi asam amino. Kandungan lemak akan mengalami penurunan, nilai tertinggi terdapat pada tempe yang diinkubasi selama 36 jam, ini diakibatkan peran dari enzim lipase yang menghidrolisis monogliserida, digliserida, trigliserida. Sedangkan kandungan karbohidrat akan mengalami penurunan dengan pengaruh tertinggi terdapat pada tempe yang diinkubasi selama 36 jam, hal ini karena aktivitas enzim amylase, selulase, xylanase dan lainlain yang merombak karbohidrat menjadi gula-gula sederhana.

Bahan kemasan dan lama inkubasi secara bersama-sama memberikan interaksi terhadap kualitas tempe kacang gude dinilai dari perubahan kandungan protein, lemak, dan karbohidrat. Nilai interaksi tertinggi antara bahan kemasan dan lama inkubasi terhadap kandungan protein terdapat pada tempe kacang gude yang dikemas dengan daun waru dan diinkubasi selama 48 jam. Nilai interaksi terhadap kandungan lemak tertinggi terdapat pada tempe yang dikemas dengan menggunakan daun waru diinkubasi selama 36 jam. Sedangkan interaksi terhadap kandungan karbohidrat memiliki nilai tertinggi pada tempe yang dikemas dengan daun pisang yang diinkubasi selama 36 jam.

\section{Saran}

Bagi Pendidik hasil penelitian dapat digunakan sebagai sumber belajar IPA SMP kelas IX pada konsep Bioteknologi. LKPD yang telah dirancang oleh peneliti dapat digunakan sebagai bahan ajar pada penerapan kurikulum 2013 yang berbasis pendekatan saintifik dengan model pembelajaran berbasis proyek/ Project Based Learning (PJBL).

Bagi peserta didik hasil penelitian yang telah didesain menjadi LKPD oleh penulis dapat digunakan sebagai sumber belajar dalam meningkatkan kemampuan psikomotor sehingga menghasilkan (mencipta) produk pangan alternatif dari kacang gude.

Bagi Masyarakat, hasil penelitian ini dapat digunakan sebagai acuan untuk membuat produk pangan alternatif yang berasal dari kacang gude atau dari bahan lain, sehingga akan memperbanyak olahan pangan yang layak dikonsumsi oleh masyarakat.

Bagi peneliti, agar dapat mengembangkan penelitian ini dengan perlakuan yang berbeda seperti perbedaan konsentrasi ragi atau produk yang berbeda seperti tahu, toge, susu dan lain-lain.

\section{DAFTAR RUJUKAN}

Astuti, N. P. 2009. Sifat Organoleptik Tempe Kedelai yang Dibungkus Plastik, Daun Pisang, dan Daun Jati. Karya Tulis Ilmiah tidak diterbitkan. 
Surakarta. Universitas

Muhammadiyah Surakarta.

Basriman, I. 2010. Pengemasan dan Penyimpanan Pangan Teori dan Aplikasinya pada Industri. Jakarta. Universitas Sahid Jakarta.

Dewi, I. W. R. 2010. Karakteristik Sensoris Nilai Gizi dan Aktivitas Anti Oksidan Tempe Kacang Gude (Cajanus cajan L. Millsp) dan Tempe Kacang Tunggak (Vigna unguiculata (L.) Walp.) dengan Berbagai Variasi Waktu Fermentasi. Skripsi tidak diterbitkan. Surakarta. Universitas Sebelas Maret.

Hidayat, N. (dkk). 2006. Mikrobiologi Industri. Yogyakarta. Andi Offset.

Mastuti, T. S., \& R. Handayani. 2014. Senawa Kimia Penyusun Ekstrak Ethyl Asetat dari Daun Pisang Batu dan Ambon Hasil Destilasi Air. Jurusan Teknologi Pangan. Universitas Pelita Harapan. ISBN 978-60299334-3-7

Salim, E. 2012. Kiat Cerdas Wirausaha Aneka Olahan Kedelai. Yogyakarta. Andi Offset.

Suprapti M. L. 2003. Pembuatan Tempe. Yogyakarta. Kanisius.

Suprihatin. 2010. Teknologi Fermentasi. Surabaya. Unesa University Press

Susiati, E. 2014. Pengaruh Variasi Pemberian Ragi dan Lama Fermentasi Terhadap Kualitas
Tempe Biji Ketapang (Terminalia catapa). Tesis tidak diterbitkan. Lampung. Universitas Muhammadiyah Metro. 